\title{
Conservation of endemic species in the national system of protected areas from Nicaragua
}

\author{
A. Mijail Pérez ${ }^{1}$, A. Meyrat ${ }^{2}$, J. Zolotoff ${ }^{3}$, O. Saldaña ${ }^{2}$, A. Medina ${ }^{2}$, G.A. Ruiz ${ }^{2}$ and M. Sotelo ${ }^{2}$ \\ 1. Gaia Association, Colonia 10 de Junio, B-501, Managua, Nicaragua, Tel: (505) 2249 3127; mijail64@gmail.com \\ 2. Independent Consultant, Managua, Nicaragua \\ 3. Zolotoff, Cocibolca Foundation, Managua, Nicaragua
}

Received 26-I-2013 Corrected 13-VII-2013 Accepted 16-VIII-2013

\begin{abstract}
Nicaragua, in the framework of the Convention on Biological Diversity $(\mathrm{CBD})$, agreed to establish a "Representative system of protected areas that adequately conserve biodiversity and terrestrial, marine and inland water ecosystems". Pursuant to the above, we conducted a Gap Analysis of Biodiversity Conservation for the National System of Protected Areas (SINAP) of Nicaragua, focused on terrestrial and inland water ecosystems as well as on terrestrial species. This paper presents the results of the analysis of the conservation status of the endemic species in the national system of protected areas of Nicaragua. The groups considered for analysis were plants, mollusks, amphibians, reptiles, and mammals. Data presented came from reviewing books, scientific papers, management plans of protected areas and unpublished reports by the authors, and nearly 140 websites. Of the 75 plant species and 31 animal species considered in the analysis, 25 species have some distribution points within the SINAP (ten of them have only one point). There are 81 species apparently absent from the SINAP. Nicaraguan endemic species are severely unprotected.
\end{abstract}

\section{KEY WORDS}

Endemism, conservation, protected areas, Nicaragua, mollusks, amphibians, reptiles, birds, mammals, plants

\section{RESUMEN}

Nicaragua, en el marco de la Convención de Diversidad Biológica (CDB), se comprometió a establecer un "Sistema representativo de áreas protegidas que conserve de forma adecuada la biodiversidad y los ecosistemas terrestres, marinos y de aguas intercontinentales". En cumplimiento de lo anterior, se realizó un Análisis de Vacíos de Conservación de la Biodiversidad para el Sistema Nacional de Áreas Protegidas (SINAP), de Nicaragua, enfocado en ecosistemas terrestres y de aguas continentales, así como especies terrestres. En el presente trabajo se presentan los resultados sobre el análisis del estado de conservación de los endemismos en el sistema nacional de áreas protegidas de Nicaragua. Los grupos considerados para el análisis fueron plantas, moluscos, anfibios, reptiles y mamíferos. Los datos presentados procedieron de la revisión de libros, artículos científicos, planes de manejo de áreas protegidas e informes inéditos de los autores, así como unas 140 páginas webs revisadas. De las 75 especies de flora y las 31 especies de fauna consideradas en el análisis, 25 especies tienen alguno de sus puntos de distribución dentro del SINAP (diez de ellas tienen un solo punto). Hay 81 especies aparentemente ausentes dentro del SINAP. Especies endémicas de Nicaragua se encuentran gravemente desprotegidas.

\section{PALABRAS CLAVE}

Endemismos, conservación, áreas protegidas, Nicaragua, moluscos, anfibios, reptiles, aves, mamíferos, plantas
Nicaragua, in the framework of the Convention on Biological Diversity (CBD) (CBD, 2004), agreed to establish a "Representative system of protected areas that adequately conserve biodiversity and terrestrial, marine and inland water ecosystems", therefore must be implemented steps for the conservation of highly threatened ecosystems (MARENA, 2011; Pérez, Siria \& Sotelo, 2005). Pursuant to the above, we conducted a Gap Analysis of Biodiversity
Conservation for the National System of Protected Areas (SINAP) of Nicaragua, focused on terrestrial, inland water ecosystems as well as terrestrial species, to help preserve them properly (MARENA, 2011).

Nicaragua is one of the countries with the highest biodiversity in the region, despite the lack of studies on this topic, as well as of programs of long-term biodiversity monitoring (Perez, 2004; Pérez, 2008). According to recent 
data it has about 12493 species of animals (10 625 species of invertebrates and 1868 of vertebrates) and 5796 species of higher plants (Pérez, 2011). Of this total there are 200 endemic species of which 104 are plants and the other animals (MARENA, 2011). Endemism is understood in the sense of Brown and Lomolino (1998), who argue that endemic species are those strictly located in an area that can be highly variable of extension, usually specific locations or geographical areas (Mayr \& Ashlock, 1993).

According to the map of ecosystems prepared by the CCAD according to UNESCO (1973), in Central America there are 114 types of ecosystems, including 65 forests, 19 types of grasslands, 9 shrub-lands, 7 types of savannas, and 14 aquatic ecosystems, including freshwater and marine. Of this total there are 68 types represented in Nicaragua (MARENA, 2001) for a $60 \%$ of the total present in the region.

This paper presents the results on the analysis about the conservation status of endemic species in the National System of Protected Areas of Nicaragua. The groups considered for analysis were plants, mollusks, amphibians, reptiles, birds and mammals. All protected areas belonging to the SINAP were considered.

The data presented came from reviewing books, scientific papers, management plans of protected areas, unpublished reports by the authors, and some 140 websites checked. Of the total of 104 plant species endemic to the country cited only 77 could be taken into account in the analysis because the rest lacked any coordinates. The endemic taxa of Nicaragua in contrast to the total number of species per group are presented in Table 1. In the case of birds there are no endemic species cited for Nicaragua (Martínez-Sánchez, 2007).

The distribution of all endemic species is presented in Figure 1. As can be seen, although there is data presence throughout the country, the area with most points is the North-Central region. Unexpectedly, in the Department of Chontales and specifically in Amerrisque protected area, with a low level of ecological integrity (MARENA, 2011) a large number of endemic species are present. The existence of gaps in the Atlantic area is probably due more to lack of information than to lack of endemism. In the case of fauna groups, spatial coverage in the country is much wider than in flora.

The distribution of endemic species of flora is associated mainly with the North-Central region but there are some endemic species in the Pacific and the Atlantic, unlike the endemic fauna which is more evenly distributed throughout the country. The orchids are 24 endemic species, Fabaceae (12), Asteraceae (seven), Myrtaceae (six), Rubiaceae (five), Myrsinaceae and Lauraceae have four endemic species each; the Asclepiadaceae and Viscaceae three species each; Acanthaceae, Araceae, Bignoniaceae, Convolvulaceae, Cyperaceae, Ericaceae, Rutaceae and

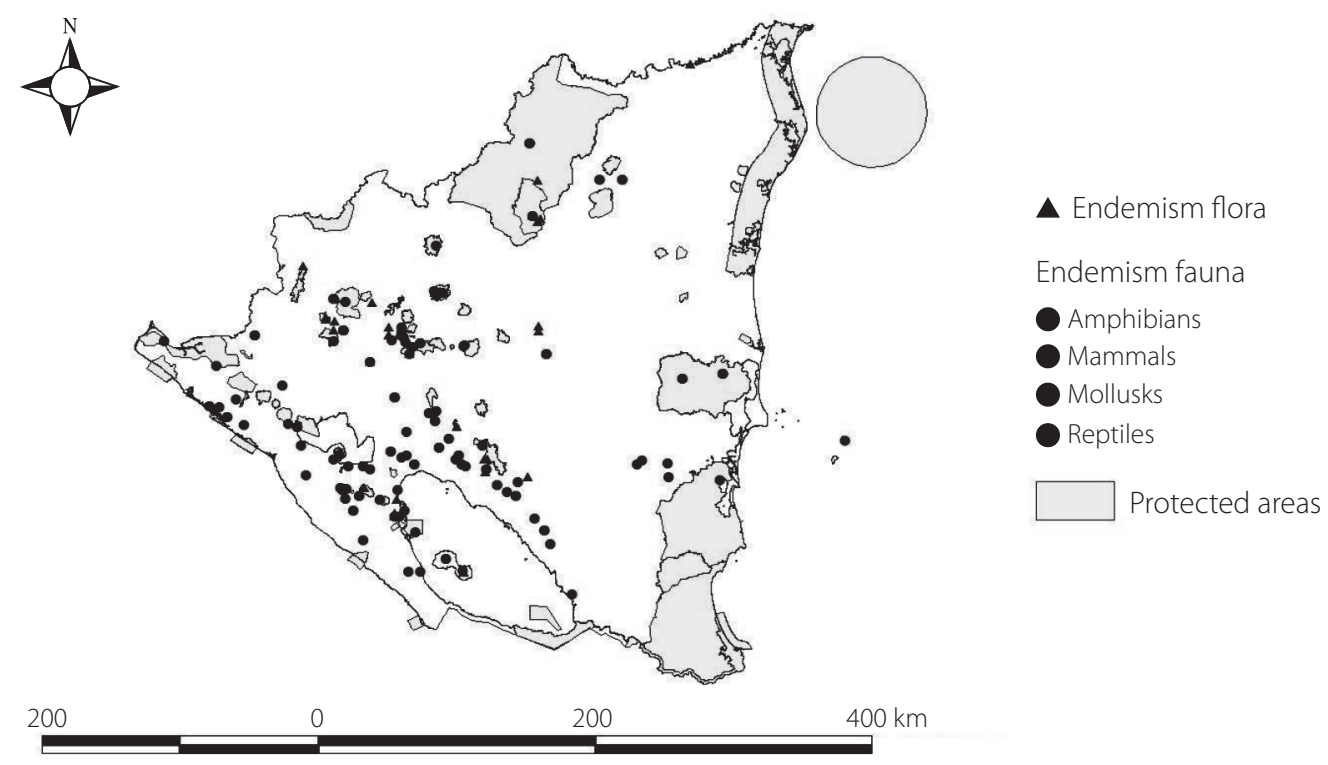

FIG. 1. Distribution of the endemic species per faunal groups. 
TABLE 1

Species endemic to Nicaragua in the groups studied.

\begin{tabular}{lcccl}
\hline \multicolumn{1}{c}{ Taxa } & $\begin{array}{c}\text { Number of } \\
\text { endemic species }\end{array}$ & $\begin{array}{c}\text { Total number } \\
\text { of species }\end{array}$ & $\begin{array}{c}\% \\
\text { endemism }\end{array}$ & \multicolumn{1}{c}{ Source } \\
\hline Flora & 104 & 5796 & 1,79 & Grijalva, 1999; Meyrat, In litt. \\
Mollusks & 15 & 1908 & 0,79 & Pérez et al., 2003 \\
Amphibians & 4 & 76 & 5,26 & $\begin{array}{l}\text { Köhler, 2002; 2003; Köhler \& } \\
\text { Sunyer, 2006; Sunyer et al., } 2008\end{array}$ \\
Reptiles & 6 & 163 & 3,68 & Köhler, 2003 \\
Mammals & 2 & 225 & 0,89 & Saldaña O. \& Medina A., In litt. \\
Total & 200 & 17380 & 15,72 &
\end{tabular}

Sabiaceae, have two endemic species each. Furthermore, the Agavaceae, Bombacaceae, Cacti, Cesalpinaceae, Campanulaceae, Chlorantaceae, Clethraceae, Crassulaceae, Cucurbitaceae, Ebenaceae, Euphorbiaceae, Lorantaceae, Piperaceae, Polygonaceae, Rosaceae, Sapindaceae, Sapotaceae, Simaroubaceae, Styracaceae, Theophrastaceae and Lamiaceae, have an endemic species per each family (Stevens, 2001).

\section{Analysis of endemism}

\section{Flora}

One thing to note is that the distribution has a zoned influence: northern species have greater influence in the North-central zone of Nicaragua with vegetation of cloud forests and pine-oak; the Pacific Zone has almost exclusive elements of the vegetation from Tehuantepec, and the Atlantic region, where species have spread from the jungles of Yucatan, added to the dry zone species just entering. Mesoamerican endemics occur most abundantly in the Atlantic and North-central regions, and its presence is lower in the Pacific region, many species endemic to the Atlantic area are in the Southeast Reserve and are shared with Costa Rica and Panama.

\section{Mollusk fauna}

According to Perez (2002) and Perez and Lopez (2002) on continental mollusks of Nicaragua endemism is associated with:

1. In the Pacific: the volcanic lakes of the region.

2. In the North Central region: the tops of many hills.

3. A particular case in the Pacific: an endemic to the islets of Granada.
The case of point 3 is Pseudopeas sp., a species new to science, which is distributed in a single point, one of the islets of Granada. This type of endemism, so closely located, indicates that if this species is removed product to disappearance or alteration of its habitat will be lost from the face of the earth without having had the opportunity to be known and studied its possible importance. This example illustrates in a clear way, the importance of conservation to the maintenance of biodiversity.

\section{Herpetofauna}

The endemism on reptiles and amphibians is mostly associated with elevations of the northern zone (Nototriton Saslaya, Rhadinaea rogerromani, Geophis dunni, Norops wermuthi) (Köhler, 2002; 2003) and the Mombacho Volcano in the Pacific slope (Bolitoglossa mombachonesis). Endemism also has elements associated with islands, as Bolitoglossa insularis, of Ometepe Island, Anolis villai, cited only from Corn Island, and Lithobates miadis, from Little Corn Island. There are also two endemic species on this group described from the Atlantic region: Craugastor chingopetaca and Bolitoglossa indio, and, taking into account the biology of this group, predictions suggest that future studies in this area of the country will lead to the discovery of new species of reptiles and amphibians to science (Köhler, 2003).

\section{Birds}

Although there are no endemic species in this group, Nicaragua has 14 species of restricted distribution according to the criteria of Birdlife International (2000): Amazilia cyanura, Aphanotriccus capitales, Carpodectes nitidus, Cyanocorax melanocyaneus, Cyrtonyx ocellatus, Dysithamnus striaticeps, Lampornis sybillae, Ortalis leucogastra, Oryzoborus nuttingi, Piprites griseiceps, Quiscalus 
nicaraguensis, Thryothorus atrogularis, Troglodytes rufociliatus, and Trogon clathratus, all with a range of distribution of less than $50000 \mathrm{~km}^{2}$.

\section{Mastozoofauna}

Mammals are the group of wildlife that has less endemism after birds, where no endemic species are present in Nicaragua. It probably happens because after birds, mammals are the second most vagile group of animals and with larger species. Endemic species are usually small in size and are mostly associated with the highlands of the North Central region of the country. The distribution of all endemism of fauna groups can be seen in Figure 2 .

\section{Protected areas and endemic species}

An important aspect to mention is the geographical asymmetry existing in the location of sites with records of endemic species in the country. There is a higher number of distribution points in the Pacific and the North-Central region than in the Atlantic region.
Of the 75 plant species and 31 animal species considered in the analysis for a total of 106 species analyzed, 25 species have some distribution points within the SINAP, for a $23,58 \%$, of those 25 species, 10 species (40\%) have only one point within the SINAP. Moreover, we have 81 species $(76,41 \%)$, which has no distribution points within the SINAP (Table 2, Fig. 1). Thus, we can conclude that our endemic species are severely unprotected.

As pointed out by Dudley and Parrish (2005) and Grooves et al. (2000), in the case of wildlife, conservation targets of "fine filter", it is difficult to try to preserve $10 \%$ of its current extent, since in many cases only scarce and / or fragmented data on the distribution of species is available for most countries of the region.

Given the difficulties of proposing some figure of territorial conservation for endemic species, urges more complete studies within and outside protected areas that allow us to know their distribution as completely as possible in order to develop their plans for long-term preservation, the latter could consider the promulgation of Private Reserves (RSP), Municipal Ecological Parks (PEM) or other figures at the municipal level.

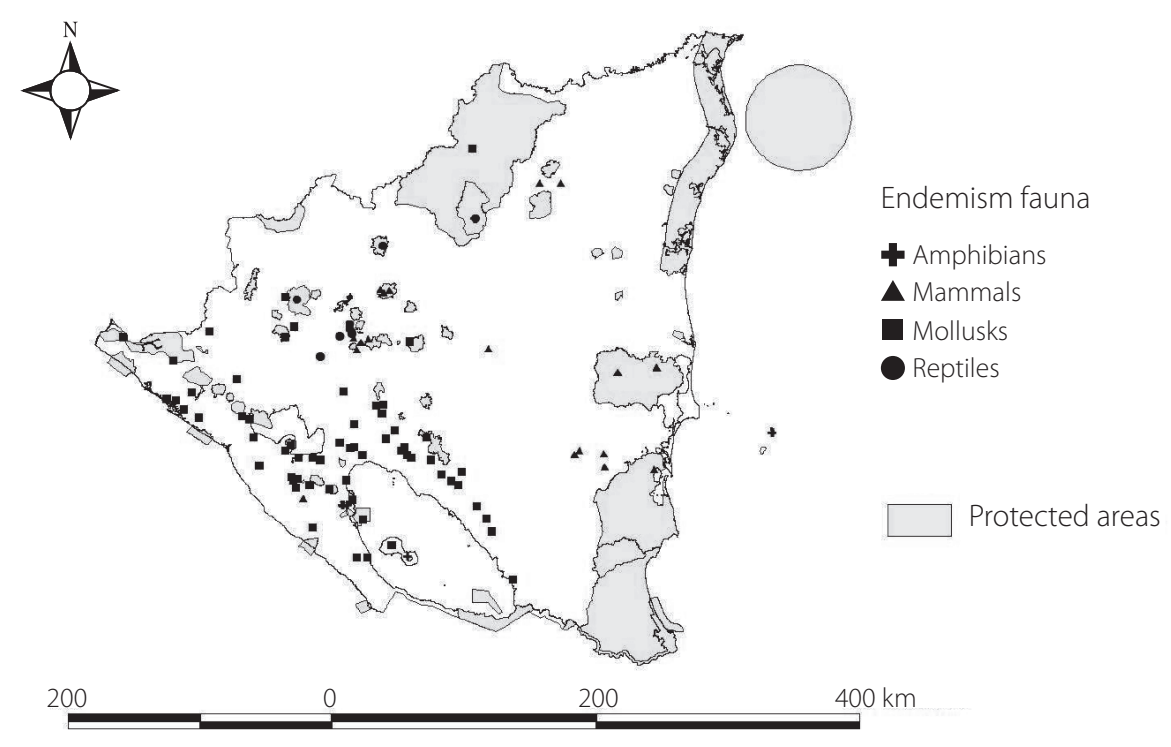

FIG. 2. Endemic species of Nicaragua. 
TABLE 2

Representation of endemism in SINAP

\begin{tabular}{|c|c|c|c|c|c|c|}
\hline No. Total & Species & Taxa & $\begin{array}{l}\text { Points } \\
\text { outside PA }\end{array}$ & $\begin{array}{c}\text { Points } \\
\text { within PA }\end{array}$ & $\begin{array}{l}\% \text { of presence } \\
\text { in } \mathrm{PA}\end{array}$ & $\begin{array}{l}\text { Total } \\
\text { Points }\end{array}$ \\
\hline 1 & Aldama mesoamericana & Flora & 1 & & 0,0 & 1 \\
\hline 2 & Amyris oblanceolata & Flora & 1 & & 0,0 & 1 \\
\hline 3 & Anisacanthus nicaraguensis & Flora & 2 & & 0,0 & 2 \\
\hline 4 & Anolis villai & Reptiles & 1 & & 0,0 & 1 \\
\hline 5 & Anolis wermuthi & Reptiles & 2 & 5 & 71,4 & 7 \\
\hline 6 & Anthurium beltianum & Flora & 1 & & 0,0 & 1 \\
\hline 7 & Aplexa nicaraguana & Mollusks & 17 & 1 & 5,6 & 18 \\
\hline 8 & Archibaccharis nicaraguensis & Flora & & 1 & 100,0 & 1 \\
\hline 9 & Ardisia ometepensis & Flora & 1 & & 0,0 & 1 \\
\hline 10 & Beckianum sinistrum & Mollusks & 56 & 3 & 5,1 & 59 \\
\hline 11 & Beckianum sp. & Mollusks & 1 & & 0,0 & 1 \\
\hline 12 & Bidens oerstediana & Flora & 1 & & 0,0 & 1 \\
\hline 13 & Biomphalaria sp. & Mollusks & 3 & & 0,0 & 3 \\
\hline 14 & Bolitoglossa indio & Amphibians & & 1 & 100,0 & 1 \\
\hline 15 & Bolitoglossa insularis & Amphibians & & 1 & 100,0 & 1 \\
\hline 16 & Bolitoglossa mombachensis & Amphibians & & 2 & 100,0 & 2 \\
\hline 17 & Bonamia douglasii & Flora & 1 & & 0,0 & 1 \\
\hline 18 & Caesalpinia nicaraguensis & Flora & 1 & & 0,0 & 1 \\
\hline 19 & Calyptranthes amarulenta & Flora & 1 & & 0,0 & 1 \\
\hline 20 & Carpodectes nitidus & Flora & 1 & 3 & 75,0 & 4 \\
\hline 21 & Centrosema seymourianum & Flora & 1 & & 0,0 & 1 \\
\hline 22 & Chondrorhyncha helleri & Flora & 1 & & 0,0 & 1 \\
\hline 23 & Clethra nicaraguensis & Flora & 1 & & 0,0 & 1 \\
\hline 24 & Coccoloba nicaraguensis & Flora & 1 & & 0,0 & 1 \\
\hline 25 & Coursetia apantensis & Flora & 1 & & 0,0 & 1 \\
\hline 26 & Coursetia paucifoliolata & Flora & 1 & & 0,0 & 1 \\
\hline 27 & $\begin{array}{l}\text { Coursetia polyphylla var. } \\
\text { acutifolia }\end{array}$ & Flora & 1 & & 0,0 & 1 \\
\hline 28 & Cranichis revoluta & Flora & 1 & & 0,0 & 1 \\
\hline 29 & Craugastor chingopetaca & Reptiles & & 1 & 100,0 & 1 \\
\hline 30 & $\begin{array}{l}\text { Dalbergia glabra var. } \\
\text { chontalensis }\end{array}$ & Flora & 1 & & 0,0 & 1 \\
\hline 31 & Diospyros morenoi & Flora & 1 & & 0,0 & 1 \\
\hline 32 & Disocactus aurantiacus & Flora & 1 & & 0,0 & 1 \\
\hline 33 & Dressleria helleri & Flora & 1 & & 0,0 & 1 \\
\hline 34 & Dysithamnus striaticeps & Flora & & 2 & 100,0 & 2 \\
\hline 35 & Epidendrum glumarum & Flora & 1 & & 0,0 & 1 \\
\hline 36 & Epidendrum hameri & Flora & 1 & & 0,0 & 1 \\
\hline 37 & Epidendrum hawkesii & Flora & 1 & & 0,0 & 1 \\
\hline
\end{tabular}


TABLE 2 (Continued...)

Representation of endemism in SINAP

\begin{tabular}{|c|c|c|c|c|c|c|}
\hline No. Total & Species & Taxa & $\begin{array}{l}\text { Points } \\
\text { outside PA }\end{array}$ & $\begin{array}{c}\text { Points } \\
\text { within PA }\end{array}$ & $\begin{array}{l}\% \text { of presence } \\
\text { in } \mathrm{PA}\end{array}$ & $\begin{array}{l}\text { Total } \\
\text { Points }\end{array}$ \\
\hline 38 & Epidendrum nicaraguense & Flora & 1 & & 0,0 & 1 \\
\hline 39 & Epidendrum vulcanicola & Flora & 1 & & 0,0 & 1 \\
\hline 40 & Eugenia esteliensis & Flora & 1 & & 0,0 & 1 \\
\hline 41 & Eugenia matagalpensis & Flora & 1 & & 0,0 & 1 \\
\hline 42 & Eugenia zelayensis & Flora & 1 & & 0,0 & 1 \\
\hline 43 & Euglandina obtusa & Mollusks & 15 & & 0,0 & 15 \\
\hline 44 & Eupatorium nicaragüense & Flora & 1 & & 0,0 & 1 \\
\hline 45 & Furcraea stratiotes & Flora & 1 & & 0,0 & 1 \\
\hline 46 & Gastrocopta gularis & Mollusks & 25 & 5 & 16,7 & 30 \\
\hline 47 & Geophis dunni & Amphibians & 1 & & 0,0 & 1 \\
\hline 48 & Glyphyalinia sp. & Mollusks & 36 & 2 & 5,3 & 38 \\
\hline 49 & Habenaria oerstedii & Flora & 1 & & 0,0 & 1 \\
\hline 50 & $\begin{array}{l}\text { Hedyosmum goudotianum } \\
\text { var. mombachanum }\end{array}$ & Flora & 1 & & 0,0 & 1 \\
\hline 51 & Helisoma nicaraguanus & Mollusks & 14 & & 0,0 & 14 \\
\hline 52 & Jacquinia montana & Flora & 1 & & 0,0 & 1 \\
\hline 53 & Jatropha stevensii & Flora & 1 & & 0,0 & 1 \\
\hline 54 & Justicia nicaraguensis & Flora & 1 & & 0,0 & 1 \\
\hline 55 & Kegeliella atropilosa & Flora & 1 & & 0,0 & 1 \\
\hline 56 & Leptinaria sp. & Mollusks & 4 & 1 & 20,0 & 5 \\
\hline 57 & Lithobates (Rana) miadis & Amphibians & 1 & & 0,0 & 1 \\
\hline 58 & Lobelia zelayensis & Flora & 1 & & 0,0 & 1 \\
\hline 59 & Lonchocarpus bicolor & Flora & 1 & & 0,0 & 1 \\
\hline 60 & Lonchocarpus pilosus & Flora & 1 & & 0,0 & 1 \\
\hline 61 & Marsdenia nicaraguensis & Flora & 1 & & 0,0 & 1 \\
\hline 62 & Marsdenia olgamarthae & Flora & & 1 & 100,0 & 1 \\
\hline 63 & Masdevallia nicaraguae & Flora & 1 & & 0,0 & 1 \\
\hline 64 & Meliosma corymbosa & Flora & 1 & & 0,0 & 1 \\
\hline 65 & Meliosma nanarum & Flora & 1 & & 0,0 & 1 \\
\hline 66 & Miradiscops opal & Mollusks & 12 & 3 & 20,0 & 15 \\
\hline 67 & Nectandra mirafloris & Flora & 1 & & 0,0 & 1 \\
\hline 68 & $\begin{array}{l}\text { Neocyclotus dysoni } \\
\text { nicaraguense }\end{array}$ & Mollusks & 7 & 5 & 41,7 & 12 \\
\hline 69 & Nototriton saslaya & Amphibians & & 2 & 100,0 & 2 \\
\hline 70 & Ocotea nicaraguensis & Flora & 1 & & 0,0 & 1 \\
\hline 71 & Ocotea strigosa & Flora & 1 & & 0,0 & 1 \\
\hline 72 & Orthogeomys matagalpae & Mammals & 1 & 5 & 83,3 & 6 \\
\hline 73 & Oryzomys dimidiatus & Mammals & 4 & & 0,0 & 4 \\
\hline
\end{tabular}


TABLE 2 (Continued...)

Representation of endemism in SINAP

\begin{tabular}{|c|c|c|c|c|c|c|}
\hline No. Total & Species & Taxa & $\begin{array}{l}\text { Points } \\
\text { outside PA }\end{array}$ & $\begin{array}{c}\text { Points } \\
\text { within PA }\end{array}$ & $\begin{array}{l}\% \text { of presence } \\
\text { in } \mathrm{PA}\end{array}$ & $\begin{array}{c}\text { Total } \\
\text { Points }\end{array}$ \\
\hline 74 & Parathesis rothschuhiana & Flora & 1 & & 0,0 & 1 \\
\hline 75 & Parmentiera trunciflora & Flora & 1 & & 0,0 & 1 \\
\hline 76 & Pentacalia matagalpensis & Flora & 1 & & 0,0 & 1 \\
\hline 77 & Peperomia matagalpensis & Flora & 1 & & 0,0 & 1 \\
\hline 78 & Phoradendron boacoi & Flora & & 1 & 100,0 & 1 \\
\hline 79 & Phoradendron molinae & Flora & 1 & & 0,0 & 1 \\
\hline 80 & Phoradendron zelayanum & Flora & 1 & & 0,0 & 1 \\
\hline 81 & $\begin{array}{l}\text { Picramnia antidesma } \\
\text { ssp. nicaraguensis }\end{array}$ & Flora & 1 & & 0,0 & 1 \\
\hline 82 & Pseudopeas sp. & Mollusks & 1 & & 0,0 & 1 \\
\hline 83 & Psittacanthus minor & Flora & 1 & & 0,0 & 1 \\
\hline 84 & $\begin{array}{l}\text { Quararibea funebris } \\
\text { ssp. nicaraguensis }\end{array}$ & Flora & 1 & & 0,0 & 1 \\
\hline 85 & Radiodiscus sp. & Mammals & 3 & 2 & 40,0 & 5 \\
\hline 86 & Randia nicaraguensis & Flora & 1 & & 0,0 & 1 \\
\hline 87 & Reithrodontomys paradoxus & Mammals & 3 & & 0,0 & 3 \\
\hline 88 & Rhadinaea rogerromani & Reptiles & & 1 & 100,0 & 1 \\
\hline 89 & Rhynchospora waspamensis & Flora & 1 & & 0,0 & 1 \\
\hline 90 & Rondeletia nicaraguensis & Flora & 1 & & 0,0 & 1 \\
\hline 91 & Rubus ostumensis & Flora & 1 & & 0,0 & 1 \\
\hline 92 & Sciurus richmondi & Mammals & 12 & 6 & 33,3 & 18 \\
\hline 93 & Scutellaria saslayensis & Flora & 1 & & 0,0 & 1 \\
\hline 94 & Serjania setulosa & Flora & 1 & & 0,0 & 1 \\
\hline 95 & Sobralia chatoensis & Flora & 1 & & 0,0 & 1 \\
\hline 96 & Sobralia triandra & Flora & 1 & & 0,0 & 1 \\
\hline 97 & Spiraxis sp. & Mollusks & 8 & 3 & 27,3 & 11 \\
\hline 98 & Stellilabium helleri & Flora & 1 & & 0,0 & 1 \\
\hline 99 & Strobilops sp. & Mollusks & 9 & 2 & 18,2 & 11 \\
\hline 100 & Styphnolobium caudatum & Flora & 1 & & 0,0 & 1 \\
\hline 101 & $\begin{array}{l}\text { Styrax nicaraguensis P. Fritsch } \\
\text { ssp. nicaraguensis }\end{array}$ & Flora & 1 & & 0,0 & 1 \\
\hline 102 & Swartzia sumorum & Flora & 1 & & 0,0 & 1 \\
\hline 103 & Vanilla helleri & Flora & 1 & & 0,0 & 1 \\
\hline 104 & X. Myrmecolaelia fuchsii & Flora & 1 & & 0,0 & 1 \\
\hline 105 & Zanthoxylum nicaraguense & Flora & 1 & & 0,0 & 1 \\
\hline \multirow[t]{2}{*}{106} & Zea nicaraguensis & Flora & & 1 & 100,0 & 1 \\
\hline & Total & & 309 & 60 & 16,26 & 369 \\
\hline
\end{tabular}

*PA: Protected Areas. 


\section{REFERENCES}

Birdlife International. (2000). Threatened birds of the world. Barcelona and Cambridge, UK: Lynx editions and Birdlife International.

Brown, J.H., \& Lomolino, M.V. (1998). Biogeografía. $2^{\text {nd }}$ edition. Sunderland, Massachussets: Sinauer associates, inc.

CBD. (2004). Convention on Biological Diversity. Retrieved from http://www.biodiv.org/convention/partners-websites. asp.

Dudley, N., \& Parrish, J. (2005). La creación de sistemas de áreas protegidas ecológicamente representativas. Mérida, Yucatán, México: The Nature Conservancy (TNC).

Grijalva, A. (1999). Diversidad de especies: flora. En: Biodiversidad en Nicaragua. Un estudio de país. Managua, Nicaragua: MARENA-PANIF.

Grooves, C., Valutis, L., Vosick, D., Neely, B., Wheaton, K. Touval, J., \& Runnels, B. (2000). Diseño de una geografía de la esperanza: Manual para la planificación de la conservación eco regional. USA: The Nature Conservancy.

Köhler, G. (2002). A New Species of Salamander of the Genus Nototriton from Nicaragua (Amphibia: Caudata: Plethodondidae). Herpetologica, 58(2), 205-210

Köhler, G. (2003). Reptiles de Centroamérica. Offenbach, Alemania: Herpeton

Köhler, G., \& Sunyer, J. (2006). A New species of Rain Frog (genus Craugastor) of the fitzingeri group from Rio San Juan southeastern Nicaragua. Senckenbergiana biologica, $86(2), 261-266$.

Martínez-Sánchez, J.C. (2007). Lista patrón de las aves de Nicaragua. Managua, Nicaragua: ALAS.

MARENA. (2001). Estado de conservación de los ecosistemas de Nicaragua. En: Estrategia Nacional de Biodiversidad. Managua, Nicaragua: Imprimatur.
MARENA. (2011). Estudio de ecosistemas y biodiversidad de $\mathrm{Ni}$ caragua y su representatividad en el sistema nacional de áreas protegidas. Managua, Nicaragua: Embajada de Dinamarca.

Mayr, E., \& Ashlock, P.D. (1993). Principles of systematic zoology. New York, USA: McGraw Hill.

Pérez, A.M. (2002). Malacogeographic regionalization, diversity and endemism in the Pacific of Nicaragua. Biogeographica, 78(3), 81-94.

Pérez, A.M. (2004). Aspectos conceptuales, análisis numérico, monitoreo y publicación de datos sobre biodiversidad. Managua, Nicaragua: Araucaria-Marena.

Pérez, A.M. (2008). Biodiversidad en Nicaragua. Contexto y estado actual. Encuentro, 79, 96-104.

Pérez, A.M. (2011). Análisis del estado de la biodiversidad y su conservación en Nicaragua y América Central. Gaia, 13, 65.

Pérez, A.M., \& López, A. (2002). Atlas de los moluscos continentales del Pacífico de Nicaragua. Managua: Nicaragua: Editorial UCA.

Pérez, A.M., Siria, I., \& Sotelo, M. (2005). Propuesta de Programa de investigación y monitoreo de la biodiversidad en áreas protegidas de Nicaragua. Informe final. MARENA-Proyecto Araucaria, Nicaragua.

Pérez, A.M., Zolototoff, J.M., \& Siria, I. (2009). Evaluación de la biodiversidad del país. Informe de consultoría, Fundación Cocibolca. Managua, Nicaragua.

Stevens, W.D. (Ed.). (2001). Flora de Nicaragua. USA: Missouri Botanical Garden Press

Sunyer, J., Lotzkat, J.S., Herts, A., Wake, D., Alemán, B., Robleto, S., \& Köhler, G. (2008). Two New species of salamanders (Genus Bolitoglossa) from Southern Nicaragua (Amphibia, Caudata, Plethodontidae). Senckenbergiana Biologica, 88(2), 319-328;

UNESCO. (1973). International mapping and classification of vegetation. UNESCO Ecology and Conservation Series 6. 